\title{
On why Uber has not taken over the world
}

\section{Peter Fleming, Carl Rhodes and Kyoung-Hee Yu}

Peter Fleming (corresponding author), University of Technology Sydney, 15 Broadway Ultimo NSW 2007, Australia, Sydney.E-mail:peter.fleming@uts.edu.au

Carl Rhodes, University of Technology Sydney, 15 Broadway Ultimo NSW 2007, Australia, Sydney.E-mail: carl.rhodes@uts.edu.au

Kyoung-Hee Yu, University of Technology Sydney, 15 Broadway Ultimo NSW 2007, Australia, Sydney.E-mail: kyoung-Hee.Yu@uts.edu.au

\begin{abstract}
Today it is common to see news headlines decrying the wildfire spread of the 'gig economy'. We ask the exact opposite question: why aren't more jobs now conducted via labour-based digital platforms, the primary method used in the gig economy? Surveys in the US, UK and elsewhere indicate that gig work remains a very minor component of the labour market, and certainly isn't overshadowing either regular employment or the contingent workforce (e.g., ondemand, part-time, contract, seasonal). The size of the gig economy is probably exaggerated because it is conflated with casual work per se (which has indeed grown) and non-labour platforms. Our paper argues that a central reason why labour-based digital platforms produce so few jobs is because it is inspired by a purist version of neoliberal capitalism, reductio ad absurdum, including strict market individualism and anti-unionism. This renders the gig economy unsustainable on its own terms, revealing its basic internal limits. The gig economy is a potent and dangerous pro-market fantasy, yet one whose imagined perfection is unsuitable to the realities of work on a large scale, hence why it has not proliferated more widely, thriving on the fringes instead.
\end{abstract}

Key Words: Future of work; gig economy; labour-based digital platforms; neoliberalism; sharing economy; Uberization.

\section{Introduction}

There has been much public and academic interest in the emergence of the 'sharing' or 'gig economy'. Sometimes dubbed 'platform capitalism' (Srnicek, 2016), this mode of employment sees individuals compete for jobs via online platforms, using a work-performed payment structure (De Stefano, 2015). It presents businesses with levels of labour flexibility not available through standard forms of waged employment because (a) payment pertains only to tasks completed and (b) workers are not classified as employees, meaning that employers can avoid the costs associated with regular jobs. 
While some celebrate labour-based digital platforms as a harbinger of individual freedom in the modern workplace (see Sundararajan, 2017), critics highlight the financial hardship that this can foster, using the neologism 'Uberization' (Hill, 2015 Fleming, 2017) to describe the conversion of regular work into contingent, itinerant and insecure 'gigs' mediated by digital algorithms and controlled by large corporations. Because gig workers are treated as independent business owners rather than employees, de facto employers are able to bypass statutory requirements like paid holiday leave, pension contributions, minimum wage, sickness insurance and protection from unfair dismissal (Stewart \& Stanford, 2017; Scholz, 2016; Martin, 2016).

Scholars and public commentators alike decry the exponential growth of the gig economy and its slew of unincorporated workers. A study by the McKinsey Global Institute (2016) estimated that the gig economy now affects up to 30 per cent of the working-age population in the United States and Europe, confirming earlier predictions regarding the rise of 'micro-jobs' (see Inuit, 2010). In his critical analysis of US employment patterns, Hill (2015, p. 2) views Uberization as a 'runaway' business model that is rapidly destroying regular work: 'it has spread outward from the tech nirvana in the Bay Area [of San Francisco] to every corner of the world. The genie has been let out of the bottle'. Other commentators speak of the imminent demise of standard jobs (Kessler, 2018) and even employment itself (Sundararajan, 2017). Adding to this impression are attention grabbing headlines such as the Huffington Post declaring, 'The Uberization of Everything is Happening' (Freeman, 2016), The Guardian announcing that 'The gig economy is coming' (Sundararajan, 2015) and on a more sanguine note, Forbes proclaiming, 'Let's Uberize the entire economy!' (Carney, 2014).

The exaggeration, especially in the popular media, likely stems from ambiguities around definition and measurement, with all kinds of insecure work (e.g., freelancing, part-time, etc.) being counted as part of the new gig economy. Reports may also include non-labour online platforms (e.g., Airbnb, revenue derived from eBay, etc.), which muddies the picture yet again. However, a closer inspection of official statistics in countries reportedly in the grip of Uberization reveals that work in the gig economy is remarkably small and marginal compared to other forms of employment. For example, the US Bureau of Labour Statistics (2018a) reports that contingent workers accounted for 1.3 per cent to 3.8 percent of total employment in May 2017. Moreover, gig workers only make up a fraction of that figure. The National Bureau of Employment Statistics estimated that 0.5 per cent of the US workforce is involved with online 
intermediaries associated with platform capitalism (Katz \& Kruger, 2016). In the United Kingdom, just 0.96 per cent of workers earned the majority of their income through interaction with the gig economy in 2017 (Department of Business, Energy and Industrial Strategy, 2017).

The above figures are surprisingly modest compared to what management consultants and the media would have us believe. In many ways the existence of the gig economy comes at the end of a long trajectory of changes to employment over the past 30 years, as characterized by the liberalization of labour laws, the growth of flexible working and the reduced power of trade unions. Gig work is the apogee of this in that it maximizes flexibility and freedom for employers in terms of how they hire and remunerate labour. Thus it is not unreasonable to assume that gig-based work would be attractive to any enterprise seeking flexible employment under minimal regulation. That is to say, we can assume that if employers in other sectors could Uberize their labour force (given the cost savings) then they probably would without much hesitation. So there must be something stalling the diffusion of on-demand digital platforms into the wider employment sector. But what?

Clearly some jobs are not amenable to being organized via the gig economy. It is hard to imagine, for example, senior managers, psychiatrists and funeral directors being employed in this way. However, the percentage of non-Uberized jobs must also include a considerable range of occupations that theoretically could be restructured in accordance with platform capitalism. Might the organized labour movement be resisting the dissemination of Uber-jobs into other occupations? Perhaps to a certain extent, but trade union activity in the OECD has been weak overall (Stewart \& Stanford, 2017; Wood et al., 2019). Moreover, even powerful unions like the Licenced Taxi Drivers Association (representing Black Cab drivers in London) have not halted the presence of Uber in the United Kingdom. What about state regulation, is that containing the gig economy? Also up to a point, but its size remains marginal even in countries where the government has been relatively favourable, such as the United States.

In seeking an alternative explanation we propose that rather than being a synonym for 'sharing', the gig economy represents an extreme variant of neoliberal capitalism for its workers. Here we follow Harvey's (2005) definition:

Neoliberalism is in the first instance a theory of political economic practices that proposes that human well-being can best be advanced by liberating individual 
entrepreneurial freedoms and skills within an institutional framework characterized by strong private property rights, free markets and free trade $[\ldots]$ state interventions in markets (once created) must be kept to a bare minimum because, according to the theory, the state cannot possibly possess enough information to second-guess market signals (prices) and because powerful interest groups will inevitably distort and bias state interventions (particularly in democracies) for their own benefit (Harvey 2005, p. 2).

This culturally pervasive form of capitalism translates into the workplace - and the gig economy or labour-based digital platforms more specifically - as the ultra-marketization, rationalization, individualization and subordination of (both private and working) life to the logic of accumulation. This mode of capitalism effectively sidesteps labour market safety nets and regulations, leaving it as a basic form of unencumbered economic exchange between capital and labour in a nominally open marketplace.

Hence our argument. Labour-based digital platforms are an almost too perfect expression of neoclassical economic theory, especially pertaining to abstract market individualism. Too perfect is the operative phrase. This version of capitalism is so pure and unalloyed (from a theoretical perspective at least) that it's largely unworkable in practice. Labour-based digital platforms bump up against the limits of feasible and reproducible economic activity, marking the logical end point of the process of neoliberalization that's been underway in economies around the world since the 1980s. Importantly, we are not suggesting that employment hasn't been significantly degraded over the last 40 years. It undoubtedly has (Standing, 2017; Kalleberg, 2018; Weil, 2017). But the gig economy still remains a minor facet of that trend for reasons we seek to explain.

\section{Defining and measuring the gig economy}

Even though the term 'gig economy' has been in use for about a decade (Uber, for example, was founded in 2009) there has been significant confusion regarding its definition and measurement. There are several causes. As previously noted, accounts in the media often conflate workers in the gig economy with those who earn revenue from capital/asset based platforms (including Airbnb and Etsy), sell goods online (eBay) and engage in 'consignment' activities with firms like YouTube (Collier et al., 2017; Constantiou et al., 2017). The labour- 
based digital platforms that concern us are distinct, involving the selling of labour time rather than acting as a landlord or selling goods and services. Furthermore, casual work, freelancing, contracting and part-time employment, while not new, are often confused with employment in the gig economy. This in turn impedes accurate measurement, since not all 'contingent' and 'alternative' work arrangements (as they are labelled in the United States, for instance) involve labour-based digital platforms or gig jobs.

Given these difficulties, our paper will precisely define the gig economy and then map this definition against available data concerning its size in a number of OECD countries. In particular, we examine the United States (where platform capitalism originated), the United Kingdom, Australia and several European countries. These countries were chosen as examples of advanced economies governed by a liberal democratic state that have embraced neoliberal reforms since the 1980s - including market deregulation, de-unionization of the workforce, privatization of public enterprises and the valuing of market relations as a natural and superior mode of socio-economic organization (Brown, 2015). It is this context that we suggest is significant for our explanation of employment trends as they relate to both the economic realities and social implications of Uberization.

\section{What is the gig economy?}

Our focus is on labour services provided via digital platforms. This is not to be confused with similar arrangements relating to self-employment, contracting work, agency jobs, part-time, seasonal roles and so-forth. The US Bureau of Labor Statistics (BLS) (2018b, n.p.) admitted to this classificatory problem in relation to its Contingent Work Supplement (CWS), which was appended to the Current Population Survey (CPS) between 1995 and 2017: 'many definitions of gig workers include people in temporary jobs, independent contractors, on-call workers, and day laborers - all of which can be estimated with CWS data. However, many definitions also include people in types of work arrangements that did not exist when the survey was last fielded'.

The notion of self-employment (which is extensively used in the gig economy) aptly illustrates the confusion. Of course, self-employment predates the emergence of the gig economy and can take on various forms. An owner operator of a bakery and a Lyft driver both fall into this category, but only the Lyft driver is a gig worker. Employment law has therefore sought to 
distinguish the 'incorporated' self-employed from the 'unincorporated' self-employed. Whereas the owner operator of the bakery is an incorporated worker - since they own and run a legal corporate entity - the Lyft driver is an 'unincorporated' worker. S/he is not legally a corporate body but nevertheless an independent business concern in his or her own right, hired by another organization in a manner that is casual and peripatetic.

However, even this distinction does not quite capture the specific characteristics of the gig economy. The term labour-based digital platforms indicates why in that it alludes to the use of an electronic intermediary (e.g., an Uber app) to match nominally private workers with consumers in a real-time, on-demand fashion. The BLS (2018b) recently made a notable innovation in this regard. When trying to isolate this category of employment, it added four new questions to its $2017 \mathrm{CWS}$, homing in on the electronic element to differentiate gig workers from other seasonal labourers, part-time employees and so-forth. They approach the gig economy as, 'electronically mediated work, defined as short jobs or tasks that workers find through websites or mobile apps that both connect them with customers and arrange payment for the tasks.' Additionally, 'in this type of employment arrangement, workers use a company's website or mobile app to connect to clients or customers and obtain short jobs, projects, or tasks are paid by or through the company that owns the website or mobile app; choose when and whether to work; and may do these short jobs, projects, or tasks in person or online' (n.p.)

A similar definition is forwarded by other researchers in the United States. For example, the US Census Bureau and National Bureau of Economic Research state,

we define 'gig employment' as one-time jobs where workers are employed on a particular task or for a defined period of time. A gig worker is not paid a wage or salary; does not have an implicit or explicit contract for a continuing work relationship; and does not have a predictable work schedule or predictable earnings when working. (Abraham et al., 2017, p. 10).

The UK government has echoed these protocols when defining the gig economy. While not as methodologically advanced as their US counterparts, the most accurate study of gig workers (commissioned by the Department of Business, Energy and Industrial Strategy, 2017 p. 4) observes, 'the gig economy involves the exchange of labour for money between individuals or 
companies via digital platforms that actively facilitate matching between providers and customers, on a short-term and payment by task basis'.

\section{Measuring the gig economy}

Due to the ambiguity surrounding the boundaries of the gig economy, measurement systems that collect data on the topic have, historically, been fraught with difficulty. However, with recent definitions yielding a more accurate and delimited picture of gig work, a number of methodologies have been developed that have aimed to gauge its size. The most ambitious attempts have been conducted in the United States. As mentioned above, since 1995 the BLS has appended a CWS to the CPS to measure contingent and alternative employment. Contingent workers are defined as 'persons who do not expect their jobs to last or who report that their jobs are temporary' and alternative workers 'identified as independent contractors, independent consultants, or freelance workers, regardless of whether they are self-employed or wage and salary workers' (BLS, 2018a, n.p.). The CPS consists of a probability selected sample of 60,000 households. The questionnaire is administered in person or over the phone and relies on both self and proxy reporting (where one household member describes the activities of all other members), with the time frame of 'last week' used.

Because contingent and alternative work arrangements are too broad for isolating digital platform workers, the $2017 \mathrm{CSW}$ added four extra questions (see Appendix One). They were designed to identify household members who had earned income through in-person electronically mediated work or jobs done entirely online. The additional questions also asked whether this was their main or secondary income source. One concern was that some respondents might not view their participation in the platform economy as paid employment and thus misreport their true status by answering 'no'. The BLS decided it would be too complicated to add further questions to control for this. Moreover, although the extra four questions were rigorously pilot tested, analysts discovered that many respondents were answering 'yes' if they used any type of app in their work environment (which happened to include a vice president of a major bank, a police officer and a surgeon), thus producing a false positive result. This was detected by comparing their answers to the confidential microdata logged in the rest of the CPS and CSW. Consequently, analysts recoded the data to control for these false positives, as well as a number of false negatives. 
In association with the National Bureau of Employment Research, Katz and Krueger (2016) conducted another study of the gig economy in the United States that was done before the BLS released results of its extended survey in September 2018. Katz and Krueger contracted the RAND Institute to administer an online survey of alternative work arrangements to individuals in its American Life Panel, with approximately 6,000 respondents invited to participate (using a compilation of methods, including a random digit dial sample and a snowball sample). Respondents were asked whether the alternative work arrangement was their only form of income and also if it was digitally mediated (so as to isolate gig workers from other employment categories). The BLS's classification hierarchy was replicated so that the data could be compared with the CWS. However, in contrast to the CSW, this study avoided proxy measurements in order to gain more accurate results. In addition, as stated in the report, 'the CWS imposes a hierarchical skip logic (e.g., if a worker is on a temporary help or on-call job, she is not asked whether she is a freelancer) that we did not follow (i.e., we asked workers on temporary help and on-call jobs if they were independent contractors or freelancers) to gather more complete information on work arrangements' (Katz \& Krueger, 2016, p. 4).

In the British context, and operationalizing the definition cited earlier, the Department of Business, Energy and Industrial Strategy (2017) used two methods of measurement. First a NatCen Panel involving a probability-based online survey of 2,184 people in Britain (excluding Northern Ireland). Panel members were randomly selected through the British Social Attitudes survey. And second, research firm YouGov Omnibus was commissioned to conduct a nonprobability online panel survey (sequenced over five waves) of 11,354 people.

Seeking to identify European trends in the gig economy, a major study was undertaken by a consortium consisting of the Foundation for European Progressive Studies, Uni Europa and the University of Hertfordshire (see Huws et al., 2017). The percentage of the population using digital labour platforms (which they termed 'crowd workers') was measured in the United Kingdom, Sweden, Germany, Austria, the Netherlands, Switzerland and Italy. Crowd work was 'defined as paid work via an online platform' (Huws et al., 2017, p.16, also see Vermeylen et al., 2017). These workers were delineated from other employment arrangements through a disaggregated data collection process. This was because, 'crowd work as a source of income may overlap with [and needs to be distinguished from] other sources of income derived from online platforms, for instance through the sale of goods' and 'online search for work via online platforms may overlap with other forms of online job-search' 
that are in fact distinct (Huws et al., 2017, p. 14). The approach allowed researchers to estimate the degree to which individuals depended on the gig economy for their primary source of income.

The researchers also commissioned Ipsos MORI to survey a random sample of the population in each country using online methods (United Kingdom [2,238 respondents], Sweden [2,416 respondents] Germany [2,180 respondents], Austria [1,969 respondents], Italy [2,199 respondents], Switzerland [2,001] and the Netherlands [2,126 respondents]). Additional faceto-face research methods were conducted in Switzerland (1,205 respondents) and the United Kingdom [1,794 respondents]. The face-to-face method was included to correct for any bias concerning internet users. As online surveys oversample respondents who regularly use the internet, the estimations provided in the studies above present a ceiling for the scale of gig work in these economies. However, in the UK case, for example, the difference between face-to-face and online respondents was found to be negligible.

\section{The size of the gig economy}

These methodologies are important for providing an accurate measurement of the gig economy, especially in light of the considerable publicity that surrounds its development. As discussed earlier, the media hype has been intense. A press release by The McKinsey Global Institute (2016), for example, attracted much media attention when it stated that the gig economy makes up 30 per cent of the workforce in the United States and United Kingdom. Such claims are commonplace. Research by the Freelancers Union, for example, asserted that up to 36 per cent of the US workforce are freelancing and thus part of the gig economy. Similarly, a study by BMO Wealth Management (2018, p. 1) in Canada argued that 'the labour market has shifted from one characterized by stable or permanent employment to a 'gig economy' of temporary or contracted employment, where an on-demand, freelance or contingent workforce is becoming the norm'.

There is little doubt that insecure and precarious employment has significantly increased in advanced capitalist countries (see ILO, 2018; OECD, 2015). The neoliberalization of many of the world's increasingly interconnected economies has been a major driver. It follows from the deregulation of employment, the decline of trade unions, stagnating wages and the valorisation of zero-hours and 'at will' contracts (Herod \& Lambert, 2016). The question is, how much of 
this can be explained by an encroaching gig economy? The results of the BLS (2018a, 2018b) survey in the US can be divided into two parts. Pertaining to the CWS, it was found that in May 2017 between 1.3 and 3.8 per cent held contingent jobs. In 2005 the figure was higher (between 1.8 per cent and 4.1 per cent of workers). Regarding alternative work arrangements, as of May 2017, 6.9 per cent were independent contractors, 1.7 per cent were on-call workers and 0.6 per cent were workers supplied by contract firms. However, the results from the extra four questions that focused on electronically mediated work are what really interest us. As it turns out, 1 per cent of workers fell into this category.

Katz and Krueger's (2016, p. 1) study indicates that workers in alternative work arrangements ('defined as temporary help agency workers, on-call workers, contract workers, and independent contractors or freelancers') consisted of 15.8 per cent of the US workforce. This figure stood at 10.7 per cent in 2005 . Workers hired out by contract companies rose from 1.4 per cent in 2005 to 3.1 per cent in 2015 (notably higher than the BLS's 2017 CWS). And finally, "workers who provide services through online intermediaries, such as Uber or Task Rabbit, accounted for 0.5 per cent of all workers in $2015^{\prime}$.

In the United Kingdom, the study commissioned by the Department of Business, Energy and Industrial Strategy (2017) found that 4.4 per cent of the population had worked in the gig economy in 2017, although only 9 per cent of this figure earned the majority of their income this way. In total then, 0.96 per cent of the working population in the United Kingdom were regular gig workers. The multiple nation survey by Huws, Spence, Syrdal and Holts (2017) revealed that the number of adults who earned more than 50 per cent of their income in the gig economy was 1.6 per cent of the population in the Netherlands, 5.1 per cent in Italy, 2.3 per cent in Austria, 2.5 per cent in Germany, 2.7 per cent in Sweden, 2.7 per cent in the United Kingdom and 3.5 per cent in Switzerland. Concerning this group, between 43-63 per cent regarded this work as their main job. In the United Kingdom, for example, 43 per cent of respondents relied on gig work as their main source of income, meaning only 1.1 per cent of workers were significant participants in the gig economy.

We included Australia in this analysis to understand how these small figures compared to an advanced economy in a very different part of the world. The Australian Bureau of Statistics (2017) shows that casual workers consisted of 25.1 per cent of the total workforce, an increase from 23.5 per cent in 2012. Much of this work is called 'full-time casual' employment, with 
large increases in the hospitality industry in particular. But how many of these jobs are located in the gig economy? A study commissioned by the New South Wales (NSW) Department of Finance, Services and Innovation (2015) gives some estimates in the state of NSW. It examined all variants of platform capitalism, including services relating to transportation, accommodation, education, labour hire and so-forth. It found that approximately 45,000 residents had earned income from gig work in the last year (or 1.6 per cent of the NSW population), with an unknown percentage of that relying on it as their sole source of income. We note that the proportion of these residents engaging in labour-based platforms (which exclude accommodation) would be smaller still. Business activity in the gig economy consisted of 4 per cent of the overall accommodation industry and 2 per cent of the point-to-point transport sector.

\section{Why is the gig economy still tiny?}

These studies of labour-based digital platforms in nine major OECD countries clearly indicate that the percentage of workers involved in the sector is surprisingly small when compared to excessive claims in the popular media. Sensational headlines about Uber colonizing the future of work are obviously unwarranted. By the same token, there is clear evidence of growing job insecurity and casualization in neoliberal economies (also see Standing, 2017; Kalleberg, 2018; Weil, 2017). This begs the question as to why the gig economy is not at the forefront of that process; for if employers could successfully apply gig-based contracts to their workforce, we surmise, then many would be doing so, taking advantage of enhanced workforce flexibility and scalability, shifting the risk or economic volatility to workers, and limiting the need for capital investment.

As we highlighted in the introduction, it would seem reasonable to assume that some jobs are simply not amenable to digital platforms and self-employment. However, that cannot be the only reason for the modest percentages since surely more than just 1.1 per cent of jobs (in the UK context, for example) could theoretically be Uberized. Government regulation might also be an impediment. But even in countries where the state is congenial to these business models, the gig economy remains marginal. And given declining union density in most of the countries we inspected, employee resistance to Uberization does not provide a compelling explanation either. 
Our paper posits another interpretation that we believe helps explain why the gig economy remains so small. Like other critics, we contend that the so-called sharing economy has little to do with sharing, especially when it comes to labour-based digital platforms. It is instead an extreme variant of capitalism, one that has been largely stripped of the vestiges of labour protection and regulation, and thus rendering employment a rudimentary matter of market based economic exchange between capital and labour. The adjective 'extreme' registers the isolating, monetarized and hyper-controlled individualism that gig work entails (also see Hill, 2015; Martin, 2016), marking it out as the logical conclusion of the liberalization and deregulation of employment that has characterized advanced capitalism to date (Baccaro \& Howell, 2011). In other words, the gig economy reflects the hallmarks of an abstract economic ideal closely associated with neoclassical theory. As Griswold (2018, n.p.) observes in relation to Uber:

Economists love Uber because it's the closest you can get to taking the pure economic theory of [neoliberal] textbooks and summoning it to life. Uber created a massive open market, governed first and foremost by the forces of supply and demand. Along the way it broke up the taxi monopoly, taught people to accept 'surge' pricing, and ushered concepts long confined to econ 101 into the popular discourse.

This brings us to our key argument. While the gig economy is a good textbook example of neoliberal economic theory applied to the real world of labour exchange, it is in fact too pure, and thus largely unworkable as a standalone entity. We suggest that labour-based digital platforms betray the limits of the logic of contemporary capitalism itself, adumbrating the absolute threshold of what economic agents can sustain. This is so not only from labour's point of view, but as we argue below, the business firm's as well.

With the word 'limit', we register the boundary of an idea's application which cannot be crossed without undermining that idea in practice. Take the example of 'free market capitalism' as celebrated by libertarian economists. A completely free market society (liberated from all state intervention) would be impossible, of course, since it would flounder on its own immanent limitations (since Polanyi [1944], revealed long ago that so-called free markets require an active state-formation in order to function). Some suggest that this intrinsic limit is true of neoliberal capitalism more generally given its abstract and overtly-ideological character (e.g., see Perelman, 2011; Duménil \& Lévy, 2011; Harvey, 2015). We agree, but believe that the gig 
economy presents a distinct and exemplary manifestation of this tendency: based on its own axiomatic principles, the gig economy - if it were dominant - simply could not reproduce itself in any sustainable manner. Hence one reason, we contend, as to why labour-based digital platforms have not been automatically rolled out across other industries and sectors.

Let us now examine these limits in more detail.

\section{Economic limitations}

A number of features of labour-based digital platforms epitomize the extreme ideals of neoliberal economic theory. The worker is largely decollectivized and individualized, technically operating as an independent business owner. Supply and demand (or 'surges') determine the nature and intensity of the work. Labour is paid only for what they do in terms of task and time. Operators take on full individual responsibility for their economic survival, absorbing overhead costs and managing the exchange of effort/motivation. Further, trade unions are difficult to develop in this isolating environment, and in some cases actively thwarted by gig firms and court rulings.

The hypothetical vision of an economic universe consisting only of independent and selfsufficient individuals who compete in an open market pervades the likes of Friedrich Hayek's The road to serfdom (1944), a seminal text in the neoliberal cannon (see Mirowski, 2013; Fleming, 2018). Uberization has merely added a computerized 'search and match' app and algorithm to technologize the libertarian dream. Hayek's economic theories are notoriously abstract, of course. Hence why a very different reality is experienced by platform workers when applied to the real world of commerce. Worker income is the most conspicuous discrepancy. In contrast to the 'rich entrepreneur' narrative that's so often used to legitimate the phenomenon, mounting evidence shows that gig workers earn significantly less compared to others performing similar tasks in both the regular and contingent economy (Kessler, 2018; Scholz, 2016; De Stefano, 2015).

Five important points follow.

First, it is clearly difficult for platform workers to earn sufficient income in the context of Western capitalism, especially with rising living costs (accommodation, energy, food, 
education, etc.) in metropolitan areas (Zhang, 2016). Contrary to the promise of 'microentrepreneurship', most gig workers do not possess enough capital or proprietary technology to engage in entrepreneurial activity and are instead relegated to the transactional workforce in an economic environment blighted by widening inequality (Ahsan, 2018). Low income stems from a business model that relies on self-employment to absorb most of the associated costs and is designed to undercut traditional service providers on price. Moreover, linking wages to supply and demand in such a devout fashion also serves to push down income. As heterodox economists have noted, most labour markets (particularly concerning unskilled and semiskilled jobs) cannot really function according to the idealized doctrine of supply and demand, especially during an economic downturn. That is because wages end up edging ever closer to zero (see Galbraith, 2008, p.154). As a result, the prospect of earning a living solely as a platform-worker begins to look like an impossible task.

Second, given the economic precarity surrounding gig work, it is probable that a significant motivation deficit will deter labour from participating in it fully, particularly in economies where vestiges of the welfare state still offers an alternative. Relatedly, it is unsurprising that, as the labour statistics discussed earlier show, most participants use it as a supplementary or secondary source of income. Hence the relatively small figures in the data concerning full-time gig workers. This gives the gig economy a rather parasitical flavour because it indirectly relies on other forms of income (be it from less precarious work, government welfare, etc.) to function rather than being a self-sustaining sector in its own right.

Third, those workers who do find themselves relying on labour-based digital platforms for their primary source of income must be prepared to work unusually long hours in order to earn a livelihood. This is borne out by the fact that surveys (in the United Kingdom, for example, [see House of Commons, Work and Pensions Committee, 2017a]) find that a high percentage of gig workers seek evermore hours and are demographically overrepresented by younger people (Huws et al., 2017), who are arguably better equipped to deal with unpredictable and sometimes extreme periods of work, as well as take on personal debt and have multiple jobs.

Fourth, the punitive management systems deployed by some firms (such as penalizing courier drivers who fail to find a replacement in the advent of their absence) can add to the pressure to continue working. Here the limits of the gig economy literally become physiological, as illustrated in the horrific case of Don Lane, an independent courier driver for UK firm DPD 
(Booth, 2018). Having been diagnosed with diabetes, Lane was unable to seek proper treatment because the company fined him $£ 150$ per day if he could not arrange a replacement. After collapsing several times at the wheel, he died in January 2018 having worked at DPD for 19years.

Fifth and finally, turning to the structure of the economy as a whole, the small returns accrued to suppliers in the platform sector results in a minimal capacity to generate system-wide value. In this sense, the old insight by John Maynard Keynes (2007 [1936]) still rings true: workers are also consumers. The relatively high wages of manufacturing workers in earlier decades generated consumption patterns that sustained demand and economic growth, as illustrated in the mythology of Henry Ford's 'five dollar day'. A decline in effective real wages (and the labour share of GDP) will inevitably have a negative effect on wider growth. The gig economy is the thin end of the wedge when it comes to a downward cycle of declining wages, low demand and stagnating productivity. Using the gig economy a generalizable model in the economy would ironically undermine capitalism rather than help it grow.

\section{Socio-Political Limitations}

In light of the economic unsustainability (from the worker's perspective) of labour-based digital platforms, a number of governments have recently realized that although the gig economy offers cheap labour to (de facto) employers and consumers, it can be fairly expensive to the state itself. A report by the UK government (2017) found that, like other low paid workers, those who participated in the gig economy accessed welfare state provisions (such as healthcare on the National Health Service), as one would expect. However, gig economy firms in the UK make no National Insurance contributions because their workforces are technically self-employed. Moreover, gig workers' pay significantly less tax contributions than regular job holders. The report concludes that 'gig economy companies are free riding on the welfare state' (House of Commons, Work and Pensions Committee, 2017b). It is not an exaggeration to deduce that if everyone was employed as gig workers then there would be no universal healthcare and no universal pension scheme in Britain. This again highlights the parasitical tendencies underscoring the gig economy; it depends on institutional resources that lie beyond its organizational remit, and to which it does not contribute, in order to operate. 
This surfaces a number of socio-political limits inherent to labour-based digital platforms. The first pertains to the negative ramifications that gig economy can have on the social and personal lives of its workers. Given the pressure to work and the coercive management systems guiding the labour process (via app-based technologies), family life, for example, inevitably suffers. As Wood, Graham and Lehdonvirta $(2019$, p. 56) demonstrate, the control mechanisms used in many gig jobs can lead to 'social isolation, working unsocial and irregular hours, overwork, sleep deprivation and exhaustion'. Overwork and fatigue are not exclusive to the gig economy, of course. However, here we can note how market individualism (the premium placed on economic self-reliance), authoritarian control (punitive fines and obtrusive app-commands) and financial desperation, all of which are relatively unremitting in the digital platform labour process, can create severe negative externalities for workers, as the awful case of Don Lane mentioned above indicates.

The second socio-political limitation necessarily follows from this: namely, the conflict and industrial antagonism that gig work can incite between labour and capital. For example, the large number of lawsuits that Uber has contended with since 2009 is unusual and clearly a drain on the company's resources. In the United States, the O'Connor v. Uber Technologies, Inc and Yucesoy v. Uber Technologies, Inc cases regarding driver misclassification (both pending at the time of writing) could potentially see 250,000 drivers reimbursed for vehicle costs and lost tips since 2013. In the United Kingdom, Uber $v$ Aslam has also challenged the self-employed status of drivers. Uber lost the initial cased and the subsequent appeal, but then appealed again to the Court of Appeal (which it lost) and now the Supreme Court (still pending).

Despite the state generally siding with platform providers in the neoliberal West (e.g., see the Supreme Court [2018] ruling regarding arbitration clauses for contract workers), one could easily surmise that the social disruption and political antagonism (not to mention considerable legal expenses) that labour-based digital platforms attract might deter industry leaders/investors in other sectors. It casts doubt not only on the scalability of digital capitalism but even its future existence given current levels of legal contestation. Indeed, the sheer number of court cases that Uber faces around the world (prolonged by interminable appeals) can easily give one the impression that 'the world is going to war with Uber' (Dickinson, 2018, n.p.). 


\section{Organizational Limitations}

The limitations discussed above are triggered by the 'negative externalities' of digital platforms. In addition, we suggest that Uberization is also dysfunctional and unsustainable on its own terms as a business model. That is to say, even in the most favourable and propitious environments (where negative externalities were minimal) the gig economy would still face severe difficulties in reproducing itself, making it unlikely that other industries and sectors would adopt labour-based digital platforms. These organizational limitations have three key features.

First, labour-based digital platforms clearly take a major cue from the neoliberal quest to deprofessionalize occupations. This drive has a long lineage. For instance, Milton Friedman (1980) famously argued that the American Medical Association should not hold a monopoly over the certification of medical practitioners. Private firms and individuals should also be able to offer their expertise in an open, competitive marketplace, providing that customers were willing to purchase such services. Similarly, Uber bypasses taxi training and certification, flirting with the informal economy in ever contentious ways.

This absence of professionalization, although liberating organizations from regulatory standards, invariably raises problems about safety and consumer confidence. Passenger security was the main reason that London City refused to renew Uber's licence in 2017. This inherent weakness of platform capitalism also extends to worker safety. For example, an Australian study of Airtasker (which offers handyman services) revealed unqualified personnel being used to break up and dispose of asbestos (Unions NSW, 2018). It's easy to see why many occupations that require expert qualifications and formal oversight (even of the most basic kind) would be legally, economically and morally wary about reinventing themselves as gigbased service providers open to all, posing a significant limit to its expansion.

Second, even if gig economy jobs could be successfully professionalized, the use of selfemployment (i.e. dealing with workers as isolated, independent business owners) represents another barrier to their proliferation. When surveying the rise of market individualism in the employment sector, Herbert Simon (1991, p. 237) remarked that treating employees as 'independent windowless Lebnitzian monads' is a risky business strategy. In many cases, formal organizations are superior to open markets when it comes to managing labour power. The social cohesiveness and cooperation that organizations foster tends to facilitate skill 
acquisition, sharing of tacit knowledge (especially team work), the coordination and motivation of staff and overall goodwill. By contrast, gig work lacks continuity and opportunities for holistic worker development, undermining complex problem solving abilities and the elicitation of discretionary effort from the workforce (Kessler, 2018). For gig firms, productivity increasingly depends on the platform's ability to embed inducements into their reward structure and utilize electronic monitoring to sanction deviant behaviour, which is far less reliable than traditional organizational controls (Friedman, 2014).

Digital platform firms clearly recognise this problem. They are ideologically smitten by the undiluted ideals of Hayekian market individualism, but want to have their cake and eat it too. On the one hand (or formal level), gig firms seek to avoid the costs/risks/responsibilities associated with regular employment (since these have been socialized through market forces as Hayek encouraged). On the other (or informal level), they desire a highly controlled, pliant and dependent workforce, deploying an unprecedented surveillance system to achieve this end.

A firm like Lyft gets away with it (i.e., having it both ways with both independent workers and high levels of control), but probably only just. In many industries, we aver, the contractual and task sequestration engendered by quasi self-employment would simply hamper organizational effectiveness and customer trust. This is illustrated by non-gig firms, in the taxi industry, for example, appropriating technologies used by platform companies, but minus the 'Lebnitzian' employment arrangements. Here the same technology is successfully integrated into a regular or contingent workforce, providing customers with a 'security premium' compared to services sourced in the gig economy.

The third organizational limit of Uberization pertains to the considerable role that speculative capital has played in shaping the contours of the gig economy, especially the major corporations involved (Langley \& Leyshon, 2017). While the innovativeness of this business model initially attracted significant venture capital and equity, overall performance has been patchy to say the least. For example, to date Uber and Lyft have never recorded profits, choosing instead to pursue high-growth business strategies and draw on sizable cash reserves to stay afloat (Sherman, 2017).

In this respect, platform capitalism (as represented by the corporations that dominate it) is beginning to look more like a risky speculative experiment conducted by wealthy plutocrats 
rather than a sound business proposition with a durable future (Airbnb is a rare exception among 'unicorn' start-ups given its profitability, but recall we are only dealing with labourbased digital platforms in this paper). Industry reluctance to adopt labour-based digital platforms is perhaps reinforced by the corporate finance strategy pursued by its major players: the need for excessive speculative investment, an expectation of long-term losses and an almost myopic growth-focused approach that is risky and without a proven track record apropos economic sustainability.

\section{Conclusion: If Uber isn't our future then what is?}

In light of the preceding analysis, our argument can be encapsulated as thus: platform capitalism represents the limit of the trajectory that economies in the United States, the United Kingdom and Australia have followed since the 1980s (in terms of employment). The gig economy reflects an unadulterated and idealistic version of capitalism as far as the labour market is concerned; indeed, it is so extreme that for many, if not most, states, workers and employers, it has pushed the possibilities of neoliberalism beyond what can be deemed as reproducible or sustainable. We contend that this is a major reason why labour-based digital platforms and gig jobs have not proliferated more thoroughly.

What does our argument mean for the future of work, if indeed that future doesn't consist of labour-based digital platforms becoming a widespread phenomenon? It might be tempting to infer from our paper that if gig jobs represent an extreme version of capitalism, then other forms of contingent work (like casual, part-time, freelance and agency jobs, for example) are somehow more moderate and employee-friendly by comparison. We do not support that inference; precarious jobs too often involve exploitation, low wages and abusive management hierarchies (see Kalleberg et al., 2000). They do not, however, apply to the letter the abstract ideals of neoclassical theory in the same uncompromising manner that gig jobs do. Most lowpaid contingent jobs actually necessitate features that (partially, at least) override the private individualism of anonymous market relations so ardently lionized by neoliberals. This does not make them any less exploitative, of course; far from it.

While gig jobs themselves are not propagating, the ideology of the gig economy and what it implies for the wider workforce clearly is. In this sense, it is not simply the number of gig jobs that matter; more importantly it is the expectations that labour-based digital platforms instil 
among employees in the rest of the economy that is troubling. A recent UK study found, for example, that an oppressive feeling of precariousness has quietly descended over most occupations, regardless of whether they are in the gig economy or not. Around 70 per cent of workers are worried about their employment situation: 'economic insecurity now stretches right throughout our labour market, including within jobs that appear safe on the surface' (Balaram \& Wallace-Stephens, 2018: n.p.). Culturally then, Uberization may operate in an insidious fashion, not only by exploiting its immediate (albeit small) workforce but by also casting millions of other jobs in a doubtful light. All of a sudden hard won rights look like questionable privileges.

Renewed regulation and legislative efforts are clearly required to reign in the gig economy. While there are indications that municipal and national authorities have started to do this, most have focused on environmental externalities (e.g., pollution) and, in the case of ride sharing platforms, addressing passenger safety concerns. For example, the European Court of Justice ruled in 2018 that Uber was a transport company and not a platform match service, thereby opening its operations to driver background checks and vehicle licensing requirements and inspections (Khan, 2018). Large North American cities such as New York City, Los Angeles, and Toronto, have recently moved to impose congestion taxes on vehicles driven in the metropolitan area in response to growth in Uber and other ride sharing vehicles.

Regulations of this sort are relatively innocuous and may even be welcomed by labour-based digital platforms given the veneer of legitimacy they can confer. However, governments and courts have been more reluctant to alter legal frameworks defining the employment status of workers in the gig economy and/or their rights to collective bargaining and work-based benefits (Collier et al., 2018). While we sympathize with scholars who have criticized the 'masterservant' bifurcation inherent in today's employment law that classifies workers as either employees at the mercy of employers or as 'independent contractors' (Lobel, 2017, p. 65; Harris \& Krueger, 2015), we do not see the creation of a third category of 'dependent contractors'/‘independent workers' as an adequate solution.

Our contribution to this discussion emphasizes the intrinsic limits of the labour-based platform business model. It is simply unable to reproduce itself for important reasons. A largely unreformed continuation of the gig economy, therefore, can only have a sapping and corrosive effect on the wider socio-economic system that props it up. As such, it certainly should not act 
as a template, either concretely or symbolically, for the employment sector as a whole. For us, this observation provides a strong case for legislative reforms that guarantee universal rights such as freedom of association, collective bargaining and access to worker's compensation and health/safety benefits. The judicial viability of this will depend on pre-existing legal norms, of course, since labour laws in the United States and Europe, for example, can vary significantly (see Thelen, 2018). Nonetheless, such legislative reforms would not only counter platform companies' abuse of gaps in the governance of emergent forms of economic activity, but more importantly, they might also begin to redress the alarming growth in the casualization of work more generally. In the absence of such reforms, while it is highly unlikely that Uberization will usurp regular work as conventionally believed, we can still expect it to have an unfavourable influence on the rights of workers far beyond its own immediate sphere.

\section{References}

Abraham, K. Haltiwanger, J., Sandusky, K. \& Speltzer, J. (2017). Measuring the gig economy: Current knowledge and open issues. National Bureau of Economic Research. Retrieved from https://aysps.gsu.edu/files/2016/09/Measuring-the-Gig-Economy-CurrentKnowledge-and-Open-Issues.pdf

Ahsan, M. (2018). Entrepreneurship and ethics in the sharing economy: A critical perspective. Journal of Business Ethics. Online first: doi 10.1007/s10551-018-3975-2

Australian Bureau of Statistics. (2017, August). 6333.0 - characteristics of employment, Australia. Retrieved from http://www.abs.gov.au/ausstats\%5Cabs@.nsf/mediareleasesbyCatalogue/A4A44798D68CAF B9CA257EEA000C5421?Opendocument

Baccaro, L. \& Howell, C. (2011). A common neoliberal trajectory: The transformation of industrial relations in advanced capitalism. Politics \& Society, 39(4), 521-563.

Balaram, B. \& Wallace-Stephens, F. (2018). Are British workers, thriving, striving, or just about surviving? Royal Society of Arts. Retrieved from 
https://www.thersa.org/discover/publications-and-articles/reports/seven-portraits-ofeconomic-security-and-modern-work-in-the-uk

BBC. (2018). Deliveroo losses deepen as investment grows. Retrieved from https://www.bbc.com/news/business-45707700

BMO Wealth Management. (2018). The gig economy. Retrieved from https://www.bmo.com/assets/pdfs/wealth/bmo gig economy report en.pdf

Booth, R. (2018). DPD courier who was fined for day off to see doctor dies from diabetes. The Guardian. Retrieved from https://www.theguardian.com/business/2018/feb/05/courier-whowas-fined-for-day-off-to-see-doctor-dies-from-diabetes

Brown, W. (2015). Undoing the demos: Neoliberalism's stealth revolution. Brooklyn, NY: Zone Books.

Carney, B.M. (2014). Let's Uberize the entire economy. Forbes, 27 October 2017. Retrieved from https://www.forbes.com/sites/realspin/2014/10/27/lets-uberize-the-entireeconomy/\#42133c254c60

Collier, R.B., Dubal, V.B. \& Carter, C. (2017). Labor platforms and gig work: The failure to regulate. Berkley: Institute for Research on Labour and Employment Working Paper No. 106-17. Retrieved from http://www.irle.berkeley.edu/files/2017/Labor-Platforms-and-GigWork.pdf

Constantiou, I., Marton, A. \& Tuunainen, V. K. (2017). Four models of sharing economy platforms. MIS Quarterly Executive, 16(4), 231-251.

Department of Business, Energy and Industrial Strategy. (2017). The characteristics of those working in the gig economy. Retrieved from http://natcen.ac.uk/media/1543748/Thecharacteristics-of-those-in-the-gig-economy.pdf

Department of Finance, Services and Innovation. (2015). Review of the Collaborative Economy in NS. Retrieved from 
https://www.finance.nsw.gov.au/sites/default/files/Deloitte Report Review Collaborative E conomy.pdf

De Stefano, D. (2015). The rise of the just-in-time workforce: On demand work, crowdwork and labor protection in the gig economy, Comparative Labor Law and Policy Journal, $37(3), 471-504$.

Dickinson, G. (2018, June 26). How the world is going to war with Uber. The Telegraph. Retrieved from https://www.telegraph.co.uk/travel/news/where-is-uber-banned/

Duménil, G. \& Lévy, D. (2011). The crisis of neoliberalism. Cambridge, MA: Harvard University Press.

Fleming, P. (2017). The human capital hoax: Work, debt and insecurity in the era of Uberization. Organization Studies, 38(5), 691-709.

Fleming, P. (2018). Sugar daddy capitalism: The dark side of the new economy. Cambridge: Polity Books.

Freeman, S. (2015, January 4). 'Uberization' of everything is happening, but not every 'Uber' will succeed. Huffington Post. Retrieved from https://www.huffingtonpost.ca/2015/04/01/uberization-uber-of-everything n 6971752.html

Friedman, G. (2014). Workers without employers: Shadow corporations and the rise of the gig economy. Review of Keynesian Economics, 2 (2), 171-188.

Friedman, M. (1980). Free to Choose: A Personal Statement. San Diego, CA: Hardcourt.

Galbraith, J. K. (2008). The predatory state. New York, NY: Free Press.

Griswold, A. (2018). Uber's secret weapon is its team of economists. Quartz. Retrieved from https://qz.com/1367800/ubernomics-is-ubers-semi-secret-internal-economicsdepartment/amp/ 
Harris, S. \& Krueger, A. (2015). A proposal for modernizing labor laws for twenty-firstcentury work: The 'independent worker'. The Hamilton Project. Retrieved from http:// www.hamiltonproject.org/assets/files/modernizing-labor-laws-for-twenty-firstcenturyworkkruegerharris.pdf [https://perma.cc/U6XE-CEUR].

Harvey, D. (2005). A brief history of neoliberalism. London: Verso.

Harvey, D. (2015). Seventeen contradictions and the end of capitalism. London: Profile Books.

Hayek, F. A. (1944). The road to serfdom. London: Routledge.

Herod, A. \& Lambert, R. (2016) Neoliberal capitalism and precarious work: Ethnographies of accommodation and resistance. Cheltenham: Edward Elgar.

Hill, S. (2015). Raw deal: How the 'Uber economy' and runaway capitalism are screwing American corkers. New York: St. Martin's Press.

House of Commons, Work and Pensions Committee. (2017a). Report: Self-Employment and the gig economy. Retrieved from https://publications.parliament.uk/pa/cm201617/cmselect/cmworpen/847/847.pdf

House of Commons, Work and Pensions Committee. (2017b).Gig economy companies free-riding on the welfare state. Retrieved from https://www.parliament.uk/business/committees/committees-a-z/commons-select/work-andpensions-committee/news-parliament-2015/gig-economy-report-published-16-17/

Huws, U., Spence, N., Syrdal, D. \& Holts, K. (2017). Work in the European gig economy. Retrieved from https://www.researchgate.net/publication/322235547 Work in the European_Gig_Econom y_FEPS_UNI-Europa_and_University_of_Hertfordshire

International Labour Organization. (2018). World employment and social outlook: Trend 2018. Geneva: ILO. 
Inuit. (2010). Inuit 2020 Report: Twenty trends that will shape the next decade. Retrieved from https://http-

download.intuit.com/http.intuit/CMO/intuit/futureofsmallbusiness/intuit_2020_report.pdf

Jones, R. W. (20160. Ex-Hermes courier says she suffered the 'life from hell' while working for the firm. The Mirror. Retrieved from http://www.mirror.co.uk/news/uk-news/ex-hermescourier-says-suffered-8660714

Kalleberg, A. L. (2018). Precarious lives: Job insecurity and well-being in rich democracies. Cambridge: Polity.

Kalleberg, A. L., Reskin, B. F. \& Hudson, K. (2000). Bad jobs in America: Standard and nonstandard employment relations and job quality in the United States. American Sociological Review, 65(2), 256-278.

Katz, L.F. \& Krueger, A.B. (2016). The rise and nature of alternative work arrangements in the United States, 1995-2015. NBER Working Paper No. 22667. Washington DC: National Bureau of Economic Research. Retrieved from https://www.nber.org/papers/w22667

Kessler, S. (2018). Gigged: The gig economy, the end of the job and the future of work. New York, NY: Cornerstone.

Keynes, J. M. (2007 [1936]). The general theory of employment, interest and money. London: Macmillan.

Khan, M. (2018, April 11). Uber suffers further blow in European court. Financial Times. Retrieved from https://www.ft.com/content/2f9c88c8-3c9e-11e8-b9f9-de94fa33a81e

Langley, P. \& Leyshon, A. (2017). Platform capitalism : The intermediation and capitalisation of digital economic circulation. Finance and Society, 3(1), 11-31.

Lobel, O. (2017). The gig economy \& the future of employment and labor law. USFL Review, $51(1), 51-74$. 
Martin, C. J. (2016). The sharing economy: A pathway to sustainability or a nightmarish form of neoliberal capitalism? Ecological Economics, 121, 149-159.

McKinsey Global Institute. (2016). Independent work: Voice, necessity and the gig economy. Retrieved from

https://www.mckinsey.com/ /media/McKinsey/Featured\%20Insights/Employment\%20and\% 20Growth/Independent $\% 20$ work $\% 20$ Choice $\% 20$ necessity $\% 20$ and $\% 20$ the $\% 20$ gig $\% 20$ econo $\underline{\text { my/Independent-Work-Choice-necessity-and-the-gig-economy-Executive-Summary.ashx }}$

Mirowski, P. (2013). Never let a serious crisis go to waste: How neoliberalism survived the financial meltdown, London: Verso.

OECD. (2015). In it together: Why less inequality benefits all. Paris: OECD.

Perelman, M. (2011). The invisible handcuffs of capitalism: How market tyranny stifles the economy by stunting workers. New York, NY: Monthly Review Press.

Polanyi, K. (1944). The great transformation. New York, NY: Farrar and Rinehart.

Rhodes, K. (2017). Uber: What countries have banned the controversial taxi app? The Independent. Retrieved from https://www.independent.co.uk/travel/news-and-advice/uber$\underline{\text { ban-countries-where-world-taxi-app-europe-taxi-us-states-china-asia-legal-a 7707436.html }}$

Scholz, T. (2016). Uberworked and underpaid. Cambridge: Polity Press.

Sherman, L. (2017). Why can't Uber make money? Forbes. Retrieved from https://www.forbes.com/sites/lensherman/2017/12/14/why-cant-uber-make$\underline{\text { money/\#45bd196e10ec }}$

Simon, H. (1991). Organisations and markets. Journal of Economic Perspectives, 5(2), 225 244.

Slee, S. (2015). What's yours is mine: Against the sharing economy. New York, NY: Or Books. 
Srnicek, N. (2016). Platform capitalism. Cambridge: Polity Press.

Standing, G. (2017). The corruption of capitalism: Why rentiers thrive and work does not pay. London: Biteback Publishing.

Stanford, J. (2017). The resurgence of gig work: Historical and theoretical perspectives. The Economic and Labour Relations Review, 28(3), 382-401.

Stewart, A. \& Stanford, J. (2017). Regulating work in the gig economy: What are the options? Economic and Labor Relations Review, 28 (3), 420-437.

Sundararajan, A. (2015, July 26) The 'gig economy' is coming: What will it mean for work? The Guardian. Retrieved from https://www.theguardian.com/commentisfree/2015/jul/26/will-we-get-by-gig-economy

Sundararajan, A. (2017). The sharing economy: The end of employment and the rise of crowdbased capitalism. Cambridge, MA: MIT Press.

Supreme Court (of the United States. (2018). Epic Systems Corp v. Lewis. Retrieved from https://www.supremecourt.gov/opinions/17pdf/16-285_q811.pdf

Thelen, K. (2018) Regulating Uber: The politics of the platform economy in Europe and the United States' Perspectives on Politics, 16(4), 938-953.

Truss, L. (2018). The conservative case for disruption. CAPX. Retrieved from https://capx.co/the-conservative-case-for-disruption/

Unions NSW. (2018). Innovation or exploitation: Busting the Airtasker myth. Retrieved from https://d3n8a8pro7vhmx.cloudfront.net/unionsnsw/pages/3135/attachments/original/1474529 110/Unions_NSW_Report_into_Airtasker.pdf?1474529110

Upwork and Freelancers Union. (2017). Freelancing in America: 2017. Retrieved from https://www.upwork.com/i/freelancing-in-america/2017/ 
US Bureau of Labor Statistics (2018a). Contingent and alternative employment arrangements summary. Retrieved from https://www.bls.gov/news.release/conemp.nr0.htm

US Bureau of Labor Statistics. (2018b). Electronically mediated work: New questions in the Contingent Worker Supplement. Retrieved from https://www.bls.gov/opub/mlr/2018/article/electronically-mediated-work-new-questions-inthe-contingent-worker-supplement.htm

Vermeylen, G., Wilkens, M., Fromm A. \& Biletta, I. (2017). Exploring self-employment in Europe. Dublin: European Foundation for the Improvement of Living and Working Conditions.

van Doorn, N. (2017). Platform labor: On the gendered and racialized exploitation of lowincome service work in the 'on-demand' economy. Information, Communication \& Society, 20(6), 898-914.

Weil, D. (2017). The fissured workplace: Why work became so bad for so many and what can be done to improve it. Cambridge MA: Harvard University Press.

Wood, A., Graham, M. \& Lehdonvirta, V. (2019). Good gig, bad gig: Autonomy and algorithmic control in the global gig economy. Work, Employment and Society, 33(1), 56-75.

Zhang, X. Q. (2016). The trends, promises and challenges of urbanisation in the world. Habitat International, 54, 241-252.

Peter Fleming is Professor at UTS Business School in Sydney, Australia. His research focuses on the transformation of work and employment in the era of neoliberal capitalism. He is the author of several books on related topics, including The death of homo economicus (2017, Pluto) and Sugar daddy capitalism: The dark side of the new economy (2019, Polity).

Carl Rhodes is Professor of Organization Studies at UTS Business School in Sydney, Australia. His research critically investigates ethico-political dimensions of organisations and working life, with a special focus on justice, equality, resistance, dissent and democracy. His 
most recent books are Disturbing business ethics: Emmanuel Levinas and the politics of organization (Routledge, 2019) and CEO society: The corporate takeover of everyday life (Zed, 2018, with Peter Bloom).

Kyoung-Hee $\mathbf{Y u}$ is Associate Professor at UTS Business School in Sydney, Australia. Kyoung-Hee's research has focused on institutional and organisational change processes affecting work and employment. Her recent work has examined collective action and politics in institutional change, the international mobility of workers and issues of inclusion, and comparative employment relations in Asia. Kyoung-Hee's work has been published in Organization Studies, the British Journal of Industrial Relations, Human Relations, and Work, Employment \& Society.

\section{Appendix 1}

Additional Questions in the 2017 Contingent Worker Supplement of the Current Population Survey

Q1 Some people find short, IN-PERSON tasks or jobs through companies that connect them directly with customers using a website or mobile app. These companies also coordinate payment for the service through the app or website.

For example, using your own car to drive people from one place to another, delivering something, or doing someone's household tasks or errands.

Does this describe ANY work (you/NAME) did LAST WEEK?

Q1a Was that for (your/NAME's) (job/(main job, (your/NAME's) second job)) or (other) additional work for pay?

Q2 Some people select short, ONLINE tasks or projects through companies that maintain lists that are accessed through an app or a website. These tasks are done entirely online, and the companies coordinate payment for the work.

For example, data entry, translating text, web or software development, or graphic design. Does this describe ANY work (you/NAME) did LAST WEEK?

Q2a Was that for (your/NAME's) (job/(main job, (your/NAME's) second job)) or (other) additional work for pay? 